\title{
Metabolisable energy concentration in perennial ryegrass pastures: multi-site analysis of effects of cultivar, nitrogen fertiliser and white clover content
}

\author{
G.P. COSGROVE ${ }^{1}$, J.M. LEE ${ }^{2}$, D.F. CHAPMAN ${ }^{3}$, D.R. STEVENS ${ }^{4}$ \\ L. ROSSI ${ }^{3}$, W.McG. KING ${ }^{5}$ and G.R. EDWARDS ${ }^{6}$ \\ ${ }^{1}$ AgResearch Ltd, Grasslands Research Centre, PB 11008, Palmerston North 4442, New Zealand \\ ${ }^{2}$ DairyNZ, Private Bag 3221, Hamilton 3240, New Zealand \\ ${ }^{3}$ DairyNZ, P.O. Box 85066, Lincoln University, Lincoln 7647, New Zealand \\ ${ }^{4}$ AgResearch Ltd, Invermay Research Centre, Private Bag 50034, Mosgiel 9053, New Zealand \\ ${ }^{5}$ AgResearch Ltd, Ruakura Research Centre, PB 3132, Hamilton 3214, New Zealand \\ ${ }^{6}$ Agriculture and Life Sciences Faculty, Lincoln University, P.O. Box 85084, Lincoln 7647, New Zealand
}

gerald.cosgrove@agresearch.co.nz

\begin{abstract}
To include metabolisable energy (ME) as a nutritive value factor for ryegrasses in the Forage Value Index (FVI) requires data for New Zealand cultivars on the effects of environmental and management factors on cultivar ranking. This study tested the hypothesis that variation among cultivars, and so ranking, is not influenced by environment, nitrogen $(\mathrm{N})$ fertiliser level or the presence or absence of white clover. Eight cultivars, grown with or without white clover and at two levels of $\mathrm{N}$ fertiliser in grazed pastures in Waikato, Manawatū, Canterbury and Southland, were sampled seasonally over 3 years and analysed for ME. There were clover, $\mathrm{N}$ and cultivar main effects on ME in most seasons, however, there were no interactions that affected cultivar ranking, indicating that data from field evaluation systems based on monocultures are reliable for the purposes of the FVI. However, data for absolute ME concentration are required from multiple sites to account for the observed cultivar $\times$ environment interactions.
\end{abstract}

Keywords: Lolium perenne, nutritive value, forage value, cultivar, nitrogen fertiliser, Trifolium repens

\section{Introduction}

An economically based Forage Value Index (FVI) has been developed for perennial and short-term ryegrasses in New Zealand. This index ranks cultivars according to their overall value to a dairy farm, taking into consideration the major plant traits that influence productivity, the economic value of increments in those traits and the performance of individual cultivars with respect to those traits (Chapman et al. 2016). Nutritive value of perennial ryegrass (Lolium perenne) cultivars will be included in the FVI using metabolisable energy (ME) concentration as the indicator trait. Metabolisable energy concentration has been selected as the indicator of nutritive value because it largely integrates the effects of individual primary chemical constituents (e.g. proteins, sugars, fibre, lipids), is usually the firstlimiting factor for milk production in pasture-based dairy production systems, it is a single parameter, and is generally well understood and used by farmers. However, it should be noted that ME may not always fully reflect nutritive value and estimates of neutral detergent fibre (NDF) and crude protein (CP) should be used with ME to fully assess the feeding value of forage and the likely production of ruminants (Waghorn 2007). A comparable economic ranking index for ryegrasses developed in Ireland, the Pasture Profit Index, uses dry matter digestibility as the measured trait for nutritive value (McEvoy et al. 2011).

There is little published information on genetic variation in ME among New Zealand perennial ryegrass cultivars, and no information on interactions between cultivars and environmental or management factors that may affect relative cultivar rankings in the FVI. These data are essential for calculating FVI performance values for individual cultivars, and for ensuring that interactions between cultivar and environmental or management factors are accounted for in evaluation systems.

The hypothesis tested in this work was that there is genetic variation in ME in New Zealand perennial ryegrass cultivars, but there are no interactions between cultivar or phenotype (e.g. heading date, tiller size and density, ploidy) and environment, $\mathrm{N}$ fertiliser level, or presence or absence of white clover. These data were collected within a multi-site study aimed to determine if ryegrass cultivar rankings for dry matter yield and nutritive value are influenced by the presence or absence of white clover in the pasture and the level of nitrogen fertiliser applied (see Chapman et al. 2018b for background information on that study).

\section{Materials and methods}

A split-plot experimental design, comprising a factorial combination of two levels of $\mathrm{N}$ fertiliser (Low-N and High-N) and two levels of white clover (Trifolium 
repens; pastures sown with (plus clover) or without white clover (minus clover)) as main plots, and eight perennial ryegrass cultivars in split-plots with 5 replications was established in 2012 at four sites with five replications (DairyNZ Scott Farm, Waikato; Massey University No 1 Dairy Farm, Manawatū; Lincoln University Research Dairy Farm, Canterbury; and AgResearch Woodlands Research Farm, Southland). Measurements were conducted for 3 years following sowing. Eight cultivars of perennial ryegrass were compared. These consisted of two cultivars (and their associated fungal endophyte (Epichloe festucae var. lolii) representing each of four phenotypes: a morphology contrast comparing 'Abermagic AR1' and 'Prospect AR37' (dense, fine-leaved) with 'Base AR37' and 'Bealey NEA2/6' (open, broad-leaved) and a heading date contrast comparing 'Commando AR37' and 'Kamo AR37' (mid-season heading) with 'One $\mathrm{C}^{50}$ AR37' and 'Alto AR37' (late-season heading). 'Base' and 'Bealey' are tetraploid cultivars and all others are diploid. Cultivars were sown as sub-plots within each of four main plots comprising all combinations of two levels of $\mathrm{N}$ fertiliser and two levels of clover, replicated five times. The levels of $\mathrm{N}$ fertiliser applied were 50 $\mathrm{kg} \mathrm{N} / \mathrm{ha} /$ year (Low-N) or $225 \mathrm{~kg} \mathrm{~N} /$ ha/year (High-N) in Waikato, Manawatū and Southland, and 100 and $325 \mathrm{~kg} \mathrm{~N} / \mathrm{ha} /$ year in Canterbury. With the exception of Southland where plots were grazed by dairy-beef cattle, plots were grazed by dairy cows. Full details of the experimental design are given in Chapman et al. (2018b), and trial management and methodology for each site is given in Lee et al. (2018) (Waikato), Cosgrove et al. (2018) (Manawatū), Chapman et al. (2018c) (Canterbury) and Stevens et al. (2018) (Southland).
Samples of whole-pasture, representing the herbage consumed were collected pre-grazing in spring (October), summer (January) and autumn (April/May) in each of the 3 years for estimation of ME concentration. On each occasion subsamples were taken either from the samples collected to estimate herbage mass that were cut by machine harvester to $5.5 \mathrm{~cm}$ above ground level (Waikato and Canterbury), or by lawn mower to $2 \mathrm{~cm}$ (Southland), or by collecting samples specifically for nutritive value using an electric sheep-shearing handpiece to cut multiple $10 \times 10 \mathrm{~cm}$ samples to $4-5 \mathrm{~cm}$ above ground level from within each cultivar plot and then bulking them into a single sample for each plot (Manawatū). Samples were either freeze-dried (Manawatū), or oven-dried at $60^{\circ} \mathrm{C}$ (Waikato, Canterbury) or at $40^{\circ} \mathrm{C}$ (Southland) (Southland), and ground to pass a $1 \mathrm{~mm}$ sieve size before analysis by near infra-red reflectance spectroscopy (NIRS; FeedTECH, AgResearch Grasslands, Palmerston North). In the NIRS calibration used in this study, ME is predicted from the concentration of digestible organic matter in dry matter $(\mathrm{DOMD} ; \mathrm{ME}=\mathrm{DOMD} \times 0.16)$, and the latter predicted from in vitro values adjusted against in vivo standards (Corson et al. 1999). The different sample drying methods used may have influenced the estimates of ME. In a recent study, freeze-drying compared with oven-drying resulted in a small $(3 \%$, or $0.35 \mathrm{MJ} \mathrm{ME} / \mathrm{kg}$ $\mathrm{DM}$ ), but significant $(\mathrm{P}<0.01)$ increase in ME (Dale et al. 2017).

Data from all sites were combined and analysed as a mixed model fitted using REML in GenStat (VSN International Ltd. 2013). Out of the planned 36 datasets (four sites $\times 3$ years $\times$ three seasons), 33 were actually obtained, and 29 used in this analysis. Missing datasets was usually because there was no harvestable herbage under the severe drought conditions in summer

Table 1 Statistical significance of main effects and first order interactions in the cross-site analysis of metabolisable energy concentration. Site abbreviations are $\mathrm{W}=$ Waikato, $\mathrm{C}=$ Canterbury, $\mathrm{S}=$ Southland, All = all four sites were sampled.

\begin{tabular}{|c|c|c|c|c|c|c|c|c|c|c|}
\hline & \multirow[t]{2}{*}{ Season } & \multirow{2}{*}{$\begin{array}{l}\text { Sites } \\
\text { available }\end{array}$} & \multicolumn{8}{|c|}{$\begin{array}{c}\text { Statistical significance } \\
\text { ( } \mathrm{P} \text { value) }\end{array}$} \\
\hline & & & Site & Nitrogen & Clover & Cultivar & $\begin{array}{l}\text { Site } x \\
\text { Cultivar }\end{array}$ & $\begin{array}{l}\mathrm{N} \times \\
\text { Clover }\end{array}$ & $\begin{array}{c}\mathrm{N} \times \\
\text { Cultivar }\end{array}$ & $\begin{array}{l}\text { Clover } x \\
\text { Cultivar }\end{array}$ \\
\hline \multirow[t]{3}{*}{ Year 1} & Spring & C, S & $<0.001$ & 0.032 & 0.541 & $<0.001$ & $<0.001$ & $<0.001$ & 0.973 & 0.982 \\
\hline & Summer & All & 0.151 & $<0.001$ & 0.151 & $<0.001$ & $<0.001$ & $<0.001$ & 0.636 & 0.020 \\
\hline & Autumn & All & $<0.001$ & 0.582 & 0.441 & $<0.001$ & $<0.001$ & 0.011 & 0.570 & 0.519 \\
\hline \multirow[t]{3}{*}{ Year 2} & Spring & All & $<0.001$ & $<0.001$ & 0.136 & $<0.001$ & $<0.001$ & 0.006 & 0.211 & 0.255 \\
\hline & Summer & W, C & $<0.001$ & $<0.001$ & $<0.001$ & $<0.001$ & $<0.001$ & $<0.001$ & 0.024 & 0.087 \\
\hline & Autumn & W, C, S & $<0.001$ & 0.028 & $<0.001$ & $<0.001$ & 0.067 & 0.003 & 0.698 & 0.297 \\
\hline \multirow[t]{3}{*}{ Year 3} & Spring & All & $<0.001$ & $<0.001$ & $<0.001$ & $<0.001$ & 0.002 & $<0.001$ & 0.348 & 0.168 \\
\hline & Summer & W, C, S & $<0.001$ & $<0.001$ & $<0.001$ & $<0.001$ & 0.250 & $<0.001$ & 0.602 & 0.158 \\
\hline & Autumn & W, C, S & 0.059 & $<0.001$ & $<0.001$ & $<0.001$ & 0.009 & $<0.001$ & 0.024 & 0.862 \\
\hline
\end{tabular}


and autumn. Four datasets that were included in the individual site papers were excluded from this analysis because the timing of sample collection was not fully consistent with the planned months. The resulting imbalance precluded statistical comparison among cultivars for the overall mean across years and seasons.

\section{Results}

The main effect of cultivar was significant $(\mathrm{P}<0.001)$ in every season of every year (Table 1 ). The site $\times$ cultivar interaction was also significant $(\mathrm{P}<0.01)$ in most seasons but overall cultivar rankings for ME (Table 2) were consistent across sites (tetraploids $>$ late-season heading diploids $>$ mid-season heading diploids). Main effects of $\mathrm{N}$ fertiliser and clover were significant in most seasons (Table 3 ). However, only one significant clover

Table 2 Overall mean metabolisable energy concentration (MJ/kg DM) of eight perennial ryegrass cultivars. Means are for sites across treatments (clover and $\mathrm{N}$ ), seasons and years. Numbers in italics are the numerical ranking position for each cultivar within each site and for the mean of all sites ( $1=$ highest, $8=$ lowest).

\begin{tabular}{|c|c|c|c|c|c|c|c|c|c|c|c|}
\hline \multirow[t]{2}{*}{ Site } & \multicolumn{8}{|c|}{ Cultivar ${ }^{1,2}$} & \multirow{2}{*}{ Mean } & \multicolumn{2}{|c|}{$\begin{array}{l}\text { Heading date } \\
\text { contrast }\end{array}$} \\
\hline & $\begin{array}{c}\text { 'Abermagic } \\
\text { AR1' }\end{array}$ & $\begin{array}{l}\text { 'Alto } \\
\text { AR37' }\end{array}$ & $\begin{array}{l}\text { 'Base } \\
\text { AR37' }\end{array}$ & $\begin{array}{l}\text { 'Bealey } \\
\text { NEA2/6' }\end{array}$ & $\begin{array}{c}\text { 'Commando } \\
\text { AR37' }\end{array}$ & $\begin{array}{l}\text { 'Kamo } \\
\text { AR37’ }\end{array}$ & $\begin{array}{l}\text { 'One }{ }^{50} \\
\text { AR37' }\end{array}$ & $\begin{array}{l}\text { 'Prospect } \\
\text { AR37' }\end{array}$ & & $\begin{array}{c}\text { Mid- } \\
\text { season }\end{array}$ & $\begin{array}{l}\text { Late- } \\
\text { season }\end{array}$ \\
\hline Waikato & $12.3 \quad 3$ & 12.24 & 12.51 & 12.52 & 12.16 & 12.08 & 12.25 & 12.07 & 12.2 & 12.0 & 12.2 \\
\hline Manawatū & 12.63 & 12.35 & 12.71 & 12.62 & 12.07 & 12.08 & 12.44 & 12.26 & 12.3 & 12.0 & 12.4 \\
\hline Canterbury & 12.43 & 12.15 & 12.52 & 12.61 & 11.87 & 11.78 & 12.24 & 11.96 & 12.1 & 11.8 & 12.2 \\
\hline Southland & 12.53 & 12.25 & 12.62 & 12.71 & 12.07 & 11.98 & 12.34 & 12.26 & 12.3 & 12.0 & 12.3 \\
\hline Mean & 12.43 & 12.25 & $12.61=$ & $12.61=$ & 12.07 & 11.98 & 12.34 & 12.16 & 12.2 & 11.9 & 12.2 \\
\hline
\end{tabular}

1 No analysis of cultivar effects across years and seasons within site was conducted because of the unbalanced number of datasets. Statistics for within site comparisons among cultivars are presented in the individual site papers (see Materials and methods for references).

2 The morphology phenotype grouping of cultivars is: 'Abermagic' and 'Prospect' = dense, fine-leaved; 'Base' and 'Bealey' = open, broad-leaved. The heading date phenotype grouping of cultivars is: 'Commando' and 'Kamo' = mid-season heading; 'Alto' and 'One ${ }^{50}$ '= late-season heading. 'Base' and 'Bealey' are tetraploid cultivars, and all others are diploid.

Table 3 Mean metabolisable energy concentration (MJ/kg DM) of pastures grown at two levels of nitrogen ( $N$ ) fertiliser and plus or minus clover in spring, summer and autumn in Years 1, 2 and 3 after sowing. Values are means across four sites (W = Waikato, $\mathrm{M}=$ Manawatū $\mathrm{C}=$ Canterbury, $\mathrm{S}=$ Southland, All = all sites were sampled) and eight perennial ryegrass cultivars.

\begin{tabular}{|c|c|c|c|c|c|c|c|c|c|c|c|}
\hline \multirow{2}{*}{$\begin{array}{l}\text { Year } \\
\text { and } \\
\text { season }\end{array}$} & \multirow{2}{*}{$\begin{array}{c}\text { Sites } \\
\text { available }\end{array}$} & \multicolumn{2}{|c|}{$\begin{array}{l}\text { Nitrogen } \\
\text { treatment }\end{array}$} & \multicolumn{2}{|c|}{$\begin{array}{l}\text { Clover } \\
\text { treatment }\end{array}$} & \multirow[b]{2}{*}{ SED ${ }^{1}$} & \multicolumn{4}{|c|}{$\begin{array}{c}\mathrm{N} \times \text { Clover } \\
\text { treatment }\end{array}$} & \multirow[b]{2}{*}{ SED } \\
\hline & & High & Low & Plus & $\begin{array}{l}\text { Minus } \\
\text { SED }\end{array}$ & & $\begin{array}{l}\text { High-N } \\
\text { plus } \\
\text { clover }\end{array}$ & $\begin{array}{l}\text { High-N } \\
\text { minus } \\
\text { clover }\end{array}$ & $\begin{array}{l}\text { Low-N } \\
\text { plus } \\
\text { clover }\end{array}$ & $\begin{array}{l}\text { Low-N } \\
\text { minus } \\
\text { clover }\end{array}$ & \\
\hline \multicolumn{12}{|l|}{ Year 1} \\
\hline Spring & $\mathrm{C}, \mathrm{S}$ & 12.4 & 12.5 & 12.5 & 12.5 & 0.05 & $12.6^{2} a b$ & $12.3 \mathrm{c}$ & $12.4 \mathrm{bc}$ & $12.7 \mathrm{a}$ & 0.08 \\
\hline Summer & All & 11.7 & 11.5 & 11.6 & 11.6 & 0.05 & $11.6 \mathrm{~b}$ & $11.9 \mathrm{a}$ & $11.7 b$ & $11.4 \mathrm{c}$ & 0.07 \\
\hline Autumn & All & 12.5 & 12.5 & 12.5 & 12.5 & 0.04 & $12.4 a b$ & $12.5 a b$ & $12.6 a$ & $12.4 b$ & 0.05 \\
\hline \multicolumn{12}{|l|}{ Year 2} \\
\hline Spring & All & 12.8 & 12.6 & 12.8 & 12.7 & 0.04 & $12.9 a$ & $12.7 \mathrm{~b}$ & $12.6 \mathrm{~b}$ & $12.7 \mathrm{~b}$ & 0.06 \\
\hline Summer & W,C & 12.0 & 11.5 & 12.2 & 11.3 & 0.06 & $12.3 a$ & $11.7 \mathrm{c}$ & $12.0 \mathrm{~b}$ & $10.9 d$ & 0.09 \\
\hline Autumn & W,C,S & 12.4 & 12.2 & 12.4 & 12.1 & 0.05 & $12.3 a$ & $12.2 a$ & $12.4 \mathrm{a}$ & $12.0 \mathrm{~b}$ & 0.07 \\
\hline \multicolumn{12}{|l|}{ Year 3} \\
\hline Spring & All & 13.1 & 12.8 & 13.1 & 12.9 & 0.04 & $13.3 a$ & $13.0 \mathrm{~b}$ & $12.9 c$ & $12.7 \mathrm{~d}$ & 0.05 \\
\hline Summer & W,C,S & 11.8 & 11.7 & 11.9 & 11.5 & 0.06 & $12.0 \mathrm{a}$ & $11.6 c$ & $11.8 \mathrm{~b}$ & $11.5 \mathrm{c}$ & 0.09 \\
\hline Autumn & W,C,S & 12.1 & 11.4 & 12.1 & 11.4 & 0.07 & $12.4 a$ & $11.8 \mathrm{~b}$ & $11.9 \mathrm{~b}$ & $10.9 c$ & 0.10 \\
\hline
\end{tabular}

1 SED, standard error of the difference between means for levels of $\mathrm{N}$ and Clover. P-values for $\mathrm{N}, \mathrm{Clover}$ and $\mathrm{N} \times \mathrm{Clover}$ are presented in Table 1 .

2 for $\mathrm{N} \times$ Clover treatments, means within a row with different letters differ significantly at $\mathrm{P}<0.05$ according to Tukey's least significant difference. 


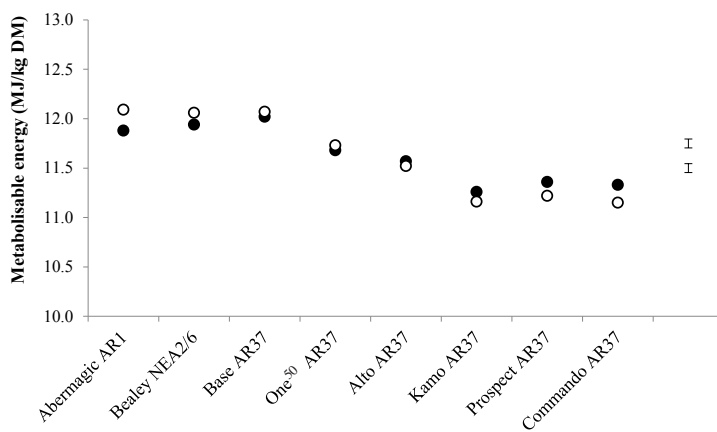

Figure 1 Significant clover $\times$ cultivar interaction detected in the cross-site analysis of metabolisable energy concentration in summer of the first year after sowing. Pastures were sown with eight different perennial ryegrass cultivars, plus $(\bullet)$ or minus $(O)$ white clover and receiving two levels of nitrogen fertiliser. The error bars indicate the maximum standard error of the difference for comparing clover treatment means for a cultivar as well as cultivars within each clover treatment.

$\times$ cultivar interaction (summer of Year 1 after sowing, $\mathrm{P}=0.02$; Table 1) and two significant $\mathrm{N} \times$ cultivar interactions (both $\mathrm{P}=0.024$; Table 1) were detected (out of a total of nine season $\times$ year combinations in each case). These were all scaling interactions (i.e. the relative difference among cultivars differed between the plus clover and minus clover treatments). There were no re-ranking interactions (i.e. where the ranking of cultivars differs between the presence and absence of clover). The clover $\times$ cultivar interaction resulted from ME being higher in the absence of clover for some cultivars ('Abermagic AR1', 'Base AR37' and 'Bealey NEA2/6') but lower for others ('Kamo AR37', 'Prospect AR37' and 'Commando AR37'; Figure 1).

\section{Discussion}

\section{Cultivar effects}

Across all sites the two tetraploid cultivars, 'Base AR37' and 'Bealey NEA2/6' (the open, broad-leaved cultivars in the morphology contrast) had the highest ME concentrations, followed by 'Abermagic AR1' (a dense, fine-leaved cultivar). The superiority of 'Base AR37' and 'Bealey NEA2/6' is consistent with the usual effect of tetraploidy on nutritive value in perennial ryegrass in pastures grazed by dairy cows (Castle \& Watson 1971; Gowen et al. 2003; O’Donovan \& Delaby 2005; Wims et al. 2013). The breeding objective behind 'Abermagic AR1' of increased water-soluble carbohydrate concentration in vegetative herbage (Humphreys 1989), does not necessarily result in higher ME, but can if the higher concentration of soluble sugars displaces indigestible structural carbohydrate. 'Prospect', the other cultivar in the dense, fine-leaved pairing, had much lower ME than 'Abermagic AR1' indicating that factors other than just morphology influence ME. A similar disparity between the two cultivars in the dense, fine-leaved pairing was also noted for dry matter yield, other parameters of nutritive value such as crude protein and fibre, and in some instances tiller density, at the four sites (Chapman et al. 2018c; Cosgrove et al. 2018; Lee et al. 2018; Stevens et al. 2018) and in the cross-site analysis (Chapman et al. 2018a). For the heading-date contrast, the mid-season heading cultivars were consistently lower in ME concentration than the late-season cultivars, and the latter were lower than the open, broad-leaved cultivars. Possible reasons for these differences among cultivars and their phenotype grouping are discussed below.

When the mean was taken across all years for the Waikato and Canterbury sites (where data were collected consistently), ME in summer of monocultures based on the mid-season heading group was $11.0 \mathrm{MJ} / \mathrm{kg}$ DM, compared with $11.4 \mathrm{MJ} / \mathrm{kg} \mathrm{DM}$ for monocultures of the late-season heading group (data not presented, but derived from the clover $\times$ cultivar interaction means for Waikato and Canterbury sites; for comparison, ME for both the dense, fine-leaved and the open broadleaved cultivars was $11.6 \mathrm{MJ} / \mathrm{kg} \mathrm{DM}$ ). This difference between phenotype groups was consistent across years, and indicates the relatively lower quality of these mid-season cultivars in summer. The lower ME of the mid-season cultivars may be related to their distinctive morphology of low tiller dry weight and lamina area/ tiller (unrelated to yield), revealed in the principal components analysis of these cultivars reported by Griffiths et al. (2017). The differences in ME did not appear to be related to fibre concentration as there were no consistent differences in NDF between the midseason and late-season heading phenotypes at any of the four sites (Chapman et al. 2018c; Cosgrove et al. 2018; Lee et al. 2018; Stevens et al. 2018).

\section{Main effects of clover and $\mathbf{N}$}

Overall, the mean proportion of white clover across sites, seasons and years (19 and 8\% for the Low-N and High-N treatments, respectively) was considered moderate to high compared with other studies of rotationally grazed dairy pastures (see Chapman et al. 2018a; these means excluded Manawatū where the proportion of clover collapsed during the first year of the trial). The main effect of clover was not significant in any of the first four seasons, but thereafter ME was higher for plus clover (12.3 MJ/kg DM) than for minus clover (11.8 MJ/kg DM). This occurred over a wide range of proportions of white clover, from greater than $40 \%$ white clover (the Low-N treatment in summer of Year 1 in Waikato, Canterbury and Southland) to less than 5\% (the High-N treatment in Manawatū throughout the trial; see Figure 1 in Chapman et al. 
2018a). The main effects of $\mathrm{N}$ treatments on ME were significant in all seasons but one (autumn of Year 1), while the $\mathrm{N} \times$ clover interaction was significant in all seasons (Table 1). The direction of the interactions varied among seasons in Year 1, indicating swards were still equilibrating. Thereafter, ME concentration was consistently highest in the High-N plus clover treatment, lowest in the Low-N minus clover treatment, and intermediate in the High-N minus clover and Low-N plus clover treatments which were often not significantly different from one another.

Thus, in a general sense, the effects of the High-N and plus clover treatments combined were additive, whereas individually they often increased ME concentration above that of the Low-N minus clover treatment to similar extents. The latter is well illustrated in the summer of Year 2 and the autumn of Year 3, when mean ME of the Low-N minus clover treatment was < $11 \mathrm{MJ}$ ME/kg DM (Table 3). In autumn of Year 3, ME increased by about $1 \mathrm{MJ} / \mathrm{kg} \mathrm{DM}$ when grass was grown with clover at the low $\mathrm{N}$ rate (Low-N plus clover) or in monoculture with the higher $\mathrm{N}$ rate (High- $\mathrm{N}$ minus clover). The response was similar in the summer of Year 2 , although in this case clover increased ME by about $1.1 \mathrm{MJ} / \mathrm{kg} \mathrm{DM}$ while the higher rate of $\mathrm{N}$ increased ME by $0.8 \mathrm{MJ} / \mathrm{kg} \mathrm{DM}$ (Table 3 ).

\section{Clover $\times$ cultivar interactions}

In this experimental design the frequency of significant clover $\times$ cultivar interactions is an indicator of the effects of grass-clover relations on the relative cultivar rankings for ME. Within sites, no significant clover $\times$ cultivar interactions in ME were detected the Waikato, Manawatū or Southland (from a total of eight, seven and nine seasonal data sets, respectively; Lee et al. 2018; Cosgrove et al. 2018; Stevens et al. 2018). Two significant interactions were detected at the Canterbury site (from a total of 9 data sets): a scaling interaction in summer of the first year, and a re-ranking interaction in summer of the second year (see Figure $3 \mathrm{~d}$ and $3 \mathrm{e}$, respectively, in Chapman et al. 2018c). There is no obvious reason why Canterbury differed from the other three sites in the occurrence of clover $\times$ cultivar interactions. The Canterbury site differed from the other sites in the use of irrigation in summer and higher application rates of $\mathrm{N}$ fertiliser for both the low and the high levels. However, with the exception of the third summer when they were higher, the proportions of clover in Canterbury did not differ greatly from Waikato or Southland (Chapman et al. 2018a).

In the cross-site analysis presented in this paper, only one significant clover $\times$ cultivar interaction for ME emerged from the nine data sets used, viz. in summer of the first year after sowing (Table 1). The ME of whole pasture was greater for some cultivars when they were grown in monoculture than when grown in mixture, but vice-versa for other cultivars (Figure 1). 'Commando AR37' and 'Kamo AR37' were among the cultivars with higher ME when grown in mixture, as they were in the two summer interactions at the Canterbury site (Chapman et al. 2018c). At the other end of the scale, the ME concentration of 'Abermagic AR1' pastures was greater in monoculture than in mixture in this cross-site analysis and in the within-site analysis for Canterbury (Chapman et al. 2018c). This is not a re-ranking interaction of the sort discussed by Chapman et al. (2018b), but rather a scaling interaction, since cultivars that ranked highly in monoculture ('Abermagic AR1', 'Base AR37' and 'Bealey NEA2/6') still ranked highly in mixture, and similarly cultivars that ranked lowly in monoculture ('Kamo AR37', 'Prospect AR37', and 'Commando AR37') also ranked lowly in mixture.

For 'Kamo AR37' and 'Commando AR37' (midseason heading date), these effects are likely explained by the higher clover proportion in mixtures based on these two cultivars compared with the two late-season heading cultivars (17.6 versus $14.0 \%$ white clover for mid-season and late-season cultivars, respectively; see Table 1, Chapman et al. 2018a). White clover generally maintains higher digestibility and ME in summer compared with grasses because it is not affected by the decline in the leaf:stem ratio that is characteristically seen in temperate grasses during reproductive growth. Hence, more white clover in summer in pastures based on 'Kamo AR37' and 'Commando AR37' compared with other cultivars could narrow the gap in ME evident for the same cultivars growing as monoculture pastures. The difference in proportions of clover between the midseason and late-season heading cultivars, and its effects on ME, can probably be explained by differences between these phenotypes of perennial ryegrass in their competitive interactions with white clover. The late-season cultivars consistently out-yielded the midseason cultivars in summer and autumn (Chapman et al. 2018a), and provided more direct competition to white clover at the time of year when conditions were favourable for its growth.

Although the frequency and magnitude of clover $\times$ cultivar interactions for ME was low, there was a discernible pattern in the three interactions (one crosssite and two within-site) which all occurred in summer and involved the two mid-season heading cultivars in all cases. There is a plausible explanation for why the relative position of these two cultivars changed, but if adjustments to the FVI were to be considered, they would be relatively small, and applied in one season (summer) for one region (Canterbury) and for one phenotype group (mid-season heading cultivars). The additional information that would be made available 
to farmers by doing so is minor, and does not justify the additional complexity that would be introduced to the FVI as a consequence. On balance, therefore, these data do not present a compelling case for adjusting performance values for ME in the FVI to account for grass-clover interactions.

\section{Conclusions}

The hypothesis that there is genetic variation among cultivars for ME, yet the ranking of cultivars is not affected by management factors such as level of $\mathrm{N}$ fertiliser or the presence or absence of clover, was supported. The only exception to this was the cultivar $\times$ environment interactions, which were detected in most seasons. The relative ranking of perennial ryegrass cultivars for ME does not differ between ryegrass monocultures and ryegrass/clover mixtures, indicating that field evaluation protocols based on monocultures (e.g. the National Forage Variety Trials: Easton et al. 2001; NZPBRA 2010; Kerr et al. 2012) provide reliable data for the purposes of the FVI. However, data for absolute ME concentration are required from multiple sites to account for the cultivar $\times$ environment interactions detected here.

\section{ACKNOWLEDGEMENTS}

The authors gratefully acknowledge Barbara Dow, DairyNZ, for conducting the statistical analyses. The Waikato and Lincoln sites were managed by DairyNZ with funding from DairyNZ Inc., and the Manawatū and Southland sites were managed by AgResearch Ltd. with funding from the Strategic Science Investment Fund. We thank the many staff from both organisations who managed the trials and collected the data.

\section{REFERENCES}

Castle, M.E.; Watson, J.N. 1971. A comparison between a diploid and a tetraploid ryegrass for milk production. Journal of Agricultural Science, Cambridge 77: 69-76.

Chapman, D.F.; Bryant, J.R.; Olayemi, M.E.; Edwards, G.R.; Thorrold, B.S.; McMillan, W.H.; Kerr, G.A.; Judson, G.; Cookson, T.; Moorhead, A.; Norriss, M. 2016. An economically based evaluation index for perennial and short-term ryegrasses in New Zealand dairy farm systems. Grass and Forage Science 72: $1-21$.

Chapman, D.F.; Crush, J.R.; Lee, J.M.; Cosgrove, G.P.; Stevens, D.R.; Rossi, L. 2018a. Implications of grassclover interactions in dairy pastures for forage value indexing systems. 6. Cross-site analysis and general discussion. New Zealand Journal of Agricultural Research 61: 255-284.

Chapman, D.F.; Lee, J.M.; Rossi, L.; Cosgrove, G.P.; Stevens, D.R.; Crush, J.R.; King, W.M.; Edwards,
G.R.; Popay, A.J. 2018b. Implications of grass-clover interactions for forage value indexing systems. 1. Context and rationale. New Zealand Journal of Agricultural Research 61: 119-146.

Chapman, D.F.; Rossi, L.; Lee, J.M.; Edwards, G.R.; Popay, A.J.; Wilson, D.J.; Bell, N.L. 2018c. Implications of grass-clover interactions in dairy pastures for forage value indexing systems. 4. Canterbury. New Zealand Journal of Agricultural Research 61: 204-229.

Corson, D.C.; Waghorn, G.C.; Ulyatt, M.J.; Lee, J. 1999. NIRS: Forage analysis and livestock feeding. Proceedings of the New Zealand Grassland Association 61: 127-132.

Cosgrove, G.P.; Popay, A.J.; Taylor, P.S.; Wilson, D.J.; Alders, L.T.; Bell, N.L. 2018. Implications of grass-clover interactions in dairy pastures for forage value indexing systems. 3. Manawatū. New Zealand Journal of Agricultural Research 61: 174-203.

Dale, T.M.; Greenfield, R.M.; Tozer, K.N.; Cameron, C.A. 2017. Post-sampling procedure affects measured nutritive value of perennial ryegrass. Journal of New Zealand Grasslands 79: 263-268.

Easton, H.S.; Baird, D.B.; Cameron, N.E.; Kerr, G.A.; Norriss, M.; Stewart, A.V. 2001. Perennial ryegrass cultivars: herbage yield in multi-site plot trials. Proceedings of the New Zealand Grassland Association 63: 183-188.

Gowen, N.; O'Donovan, M.; Casey, I.; Rath, M.; Delaby, L.; Stakelum, G. 2003. The effect of grass cultivars differing in heading date and ploidy on the performance and dry matter intake of spring calving dairy cows at pasture. Animal Research 52: 321-336.

Griffiths, W.; Matthew, C.; Lee, J.M.; Chapman, D.F. 2017. Is there a tiller morphology ideotype for yield differences in perennial ryegrass (Lolium perenne L.)? Grass and Forage Science 72: 700-713.

Humphreys M.O. 1989. Water-soluble carbohydrates in perennial ryegrass breeding. I. Genetic differences among cultivars and hybrid progeny grown as spaced plants. Grass and Forage Science 44: 231-236.

Kerr, G.A.; Chapman, D.F.; Thom, E.R.; Matthew, C.; Van der Linden, A.; Baird, D.B.; Johnston, E.; Corkran, J.R. 2012. Evaluating perennial ryegrass cultivars: improving testing. Proceedings of the New Zealand Grassland Association 74: 127-135.

Lee, J.M.; Chapman, D.F.; Wims, C.M.; Griffith, W.M.; Popay, A.J.; Wilson, D.J.; Bell, N.L. 2018. Implications of grass-clover interactions in dairy pastures for forage value indexing systems. 2 . Waikato. New Zealand Journal of Agricultural Research 61: 147-173.

McEvoy, M.; O’Donovan, M.; Shalloo, L. 2011. Development and application of an economic ranking index for perennial ryegrass cultivars. Journal of 
Dairy Science 94: 1627-1639.

NZPBRA. 2010. National Forage Variety Trials (NFVT) - Trial Protocol July 2010. New Zealand Plant Breeding and Research Association.

O'Donovan, M.; Delaby, L. 2005. A comparison of perennial ryegrass cultivars differing in heading date and grass ploidy with spring calving dairy cows grazed at two different stocking rates. Animal Research 54: 337-350.

Stevens, D.R.; Bryson, B.J.; Ferguson, C.M.; Wilson, D.J.; Bell, N.L.; Aalders, L.T.; Popay A.J. 2018. Implications of grass-clover interactions in dairy pastures for forage value indexing systems. 5.
Southland. New Zealand Journal of Agricultural Research 61: 230-254.

VSN International. 2013. GenStat for Windows 16th Edition. Hemel Hempstead, UK: VSN International. https://www.vsni.co.uk/downloads/genstat/16thedition-upgrade/

Waghorn, G.C. 2007. What is dietary metabolisable energy? Proceedings of the New Zealand Grassland Association 69: 153-159.

Wims, C.M.; McEvoy, M.; Delaby, L.; Boland, T.M; O'Donovan, M. 2013. Effect of perennial ryegrass (Lolium perenne L.) cultivars on the milk yield of grazing dairy cows. Animal 7: 410-421. 
